\title{
Purification and characterization of a lecithin-dependent haemolysin from Escherichia coli transformed by a Vibrio parahaemolyticus gene
}

\author{
Sumio Shinoda, ${ }^{1 *}$ Hideomi Matsuoka, ${ }^{1}$ Takefumi Tsuchie, ${ }^{1}$ Shin-Ichi Miyoshi, ${ }^{1}$ \\ Shigeo Yamamoto, ${ }^{1}$ Hatsumi Taniguchi $^{2}$ and Yasuo Mizuguchi ${ }^{2}$ \\ ${ }^{1}$ Faculty of Pharmaceutical Sciences, Okayama University, Tsushima, Okayama 700, Japan \\ ${ }^{2}$ School of Medicine, University of Occupational and Environmental Health, Ishigaoka, Yahatanishi, \\ Kitakyushu 807, Japan
}

(Received 29 April 1991; revised 16 July 1991; accepted 15 August 1991)

\begin{abstract}
Lecithin-dependent haemolysin (LDH) of Vibrio parahaemolyticus was purified from Escherichia coli $\mathrm{C} 600$ transformed with a plasmid (pHL591) ligated with a $1.5 \mathrm{~kb}$ DNA fragment of $V$. parahaemolyticus. The final preparation comprised two LDH proteins with different molecular masses which were immunologically crossreactive and had the same enzymic activity. The LDH was a phospholipase hydrolysing both fatty acid esters of phospholipid, i.e. it hydrolysed phosphatidylcholine (PC) to lysophosphatidylcholine (LPC) and then LPC to glycerophosphorylcholine (GPC). From this point of view, LDH should be classified as a phospholipase B. Phospholipase B, however, does not usually show haemolytic activity, because the intermediate (LPC), which is the actual haemolytic agent, is immediately hydrolysed to the final product (GPC). On the other hand, LPC formed by LDH action was comparatively stable, because the rates of the two reactions catalysed by LDH, PC to LPC and LPC to GPC, are almost the same. This is the reason that LDH shows haemolytic activity. Therefore, LDH of $V$. parahaemolyticus is an atypical phospholipase to be designated as phospholipase $\mathrm{A}_{2}$ /lysophospholipase.
\end{abstract}

\section{Introduction}

Vibrio parahaemolyticus is a slightly halophilic bacterium and a major causative agent of food poisoning in Japan. Although several kinds of haemolysins have been reported as potential pathogenic factors, the actual cause of the diarrhoea has not been clarified. Among these haemolysins, thermostable direct haemolysin (TDH) is the best-documented toxin, and is well known as the causative agent of Kanagawa phenomenon, a haemolysis on a blood-agar medium caused by pathogenic strains of the vibrio (Sakazaki et al., 1968; Miyomoto et al., 1969; Miwatani \& Takeda, 1976). TDH-related haemolysins produced by KP-negative strains of $V$. parahaemolyticus (Honda et al., 1988, 1989) or vibrios other than $V$. parahaemolyticus (Yoh et al., 1986a,b) have also been reported. Delta-VPH is a haemolysin produced by a

Abbreviations: GPC, glycerophosphorylcholine; LDH, lecithindependent haemolysin; LPC, lysophosphatidylcholine; PC, phosphatidylcholine; PLase, phospholipase.

The amino acid sequence data reported in this paper have been submitted to PIR and have been assigned the accession number A39996 [LDH(S)] and B39996 [LDH(L)]. strain of Escherichia coli transformed by a plasmid containing a DNA fragment of $V$. parahaemolyticus, but the production of delta-VPH by the donor vibrio has not been demonstrated (Taniguchi et al., 1990).

Yanagase et al. (1970) reported a haemolytic factor of $V$. parahaemolyticus which was activated by the addition of lecithin (phosphatidylcholine) and was denoted as lecithin-dependent haemolysin (LDH). We purified LDH from a culture supernatant of $V$. parahaemolyticus, but the yield of the final preparation was too small to allow its characterization. In the course of cloning the TDH gene of $V$. parahaemolyticus, Taniguchi et al. (1985, 1986) obtained a transformant [E. coli C600(pHL591)] producing $\mathrm{LDH}$, which was designated as thermolabile haemolysin in their paper. The transformant has a $1.5 \mathrm{~kb}$ HindIII-HincII DNA fragment of $V$. parahaemolyticus and produces LDH using the endogenous vibrio promoter. We found that LDH produced by the transformant is localized in the periplasmic space of the cell and is easily released by osmotic shock treatment. Thus, we could obtain an LDH fraction with high specific activity. This paper shows the existence of two immunologically crossreactive $\mathrm{LDH}$ molecules and the atypical property of LDH as a phospholipase (PLase). 


\section{Methods}

Purification of $L D H$. LDH was purified from a periplasmic fraction of the transformant $E$. coli C600(pHL591) (Taniguchi et al., 1986). The seed inoculum was prepared by cultivating the cells in $5 \mathrm{ml}$ heart infusion (HI) broth (Difco) at $37^{\circ} \mathrm{C}$ overnight without shaking, and inoculated into $500 \mathrm{ml} \mathrm{HI}$ broth. Cultivation was carried out at $37^{\circ} \mathrm{C}$ for $16 \mathrm{~h}$ with shaking $\left(80\right.$ cycles $\left.\mathrm{min}^{-1}\right)$. The cells were harvested and washed with saline by centrifugation at $7000 \mathrm{~g}$ for $40 \mathrm{~min}$. A periplasmic fraction was obtained by an osmotic shock method described by Neu \& Heppel (1965). Briefly, the washed cell pellet obtained from 31 of the culture was suspended in $100 \mathrm{ml}$ cold water. The suspension was centrifuged at $7000 \mathrm{~g}$ for $40 \mathrm{~min}$ and the supernatant was collected as the periplasmic fraction. Ammonium sulphate was added to $65 \%$ saturation, and the precipitate was collected oy centrifugation. The precipitate was resuspended in $3 \mathrm{ml} 20 \mathrm{~mm}$ histidine/ $\mathrm{HCl}$ buffer (pH 5.5), dialysed against 1 litre of the buffer and applied to a Pharmacia LKB Fast Protein Liquid Chromatography system equipped with a Mono Q HR 5/5 anion exchange column. The column was washed with $16 \mathrm{ml} 20 \mathrm{~mm}$-histidine/ $\mathrm{HCl}$ buffer and the fractions were eluted with $14 \mathrm{ml} 0.9 \mathrm{M}-\mathrm{NaCl} / 20 \mathrm{~mm}$-histidine $/ \mathrm{HCl}$ buffer. Lecithin-dependent haemolytic activity of each fraction was assayed as described below and fractions with haemolytic activity were pooled. The LDH preparation thus obtained from the transformant is designated as $\mathrm{Tr}-\mathrm{LDH}$, while LDH produced by $V$. parahaemolyticus is designated as $\mathrm{Vp}$-LDH.

To obtain a preparation of $\mathrm{Vp}-\mathrm{LDH}$, a clinical strain, $V$. parahaemolyticus MY 80-11 (Research Institute for Microbial Diseases, Osaka University, Osaka, Japan), was cultivated in $\mathrm{HI}$ dialysate medium [ $200 \mathrm{~g} \mathrm{HI}$ medium powder dissolved in 1.61 water, and then dialysed against $6.411 .5 \%(w / v) ~ N a C l$ solution] at $37^{\circ} \mathrm{C}$ for $40 \mathrm{~h}$. The LDH preparation obtained by ammonium sulphate fractionation $(65 \%$ saturation) of the culture supernatant was suspended in $3 \mathrm{ml} 20 \mathrm{mM}$ histidine/ $\mathrm{HCl}$ buffer and dialysed against the buffer overnight. The dialysed preparation was centrifuged at $100000 \mathrm{~g}$ for $120 \mathrm{~min}$ and the supernatant was used as a partially purified Vp-LDH.

Protein assay. The amount of protein was determined by the Lowry method with bovine serum albumin as the standard.

Determination of haemolytic activity. A $0.1 \mathrm{ml}$ aliquot of sample solution containing $0.9 \% \mathrm{NaCl}$ was mixed with $0.3 \mathrm{ml} 1.3 \%(\mathrm{v} / \mathrm{v})$ sheep erythrocyte suspension in $0.9 \% \mathrm{NaCl} / 10 \mathrm{mM}$-Tris/HCl buffer $(\mathrm{pH} 7.5)$ containing $10 \mu \mathrm{g}$ phosphatidylcholine (PC) (egg-yolk lecithin, type XIII-E, Sigma and the mixture was incubated at $37^{\circ} \mathrm{C}$. After $1 \mathrm{~h}$ incubation, $2.5 \mathrm{ml} 0.9 \% \mathrm{NaCl}$ solution was added and the mixture was centrifuged at $1000 \mathrm{~g}$ for $15 \mathrm{~min}$. Haemolysis was determined by measuring the $A_{540}$ of the supernatant and the haemolytic activity, in haemolytic units (HU), was expressed as the reciprocal of the dilution of the haemolysin solution which showed $50 \%$ haemolysis.

Determination of phospholipase and lysophospholipase activity. Hydrolysis of PC to lysophosphatidylcholine (LPC) or LPC to glycerophosphorylcholine (GPC) was determined by measuring the decrease in the amount of fatty acid ester residues of the phospholipids by the hydroxamate method (Nishida \& Tamiya, 1986). Sample solution $(40 \mu \mathrm{l})$ was mixed with $160 \mu \mathrm{l}$ Tris/ $\mathrm{HCl}$ buffer containing $0.125 \%$ Triton X-100, 0.025 M-CaCl, $0.875 \mathrm{~mm}$-EDTA and $2.5 \mathrm{~mm}-\mathrm{PC}$, and incubated at $37^{\circ} \mathrm{C}$ for $30 \mathrm{~min}$. Ethanol $(400 \mu \mathrm{l})$ and $1 \mathrm{M}$-hydroxylamine $/ 1.75 \mathrm{M}-\mathrm{NaOH}$ solution $(200 \mu \mathrm{l})$ were added and the mixture was incubated for $30 \mathrm{~min}$ at room temperature. Finally $120 \mu \mathrm{l} 3.3 \mathrm{M}-\mathrm{HCl}$ and $100 \mu \mathrm{l} \mathrm{FeCl}$ solution $\left(50 \mathrm{~g} \mathrm{FeCl}{ }_{3} \cdot 6 \mathrm{H}_{2} \mathrm{O}\right.$ dissolved in $10 \mathrm{ml}$ $3.6 \mathrm{M}-\mathrm{HCl}$, and then diluted nine times with ethanol) were added and $A_{520}$ was measured.
Electrophoresis. PAGE was carried out by the method of Davis \& Ornstein (1986) with $12 \%(w / v)$ acrylamide gel. SDS-PAGE was carried out by the method of Laemmli (1970) with $12.5 \%(w / v)$ acrylamide gel. The gels were stained with $0 \cdot 25 \%$ Coomassie brilliant blue.

Determination of $\mathrm{N}$-terminal amino acid sequence. Protein bands from PAGE were transferred to siliconized glass fibre sheet by electroblotting (Eckerson et al., 1988) and the N-terminal amino acid sequence was determined with a Pulse-liquid Sequencer (model 477A, Applied Biosystems).

TLC of phospholipids. Phospholipid spots on a silica gel 60 plate were developed with chloroform/methanol/water $(65: 35: 5$, by vol.) and detected by spraying with $50 \%(\mathrm{v} / \mathrm{v}) \mathrm{H}_{2} \mathrm{SO}_{4}$ and drying at $200{ }^{\circ} \mathrm{C}$ for $20 \mathrm{~min}$.

GLC of fatty acids. Fatty acids were converted to their methyl ester derivatives (Carreau \& Dubacq, 1978) and analysed with a gas chromatograph equipped with a flame-ionization detector (GC-6AM, Shimadzu, Japan). Gas chromatographic conditions were as follows: column, $15 \%$ DEGS on Uniport HP (80-100 mesh), $1.5 \mathrm{~m} \times 3 \mathrm{~mm}$ i.d.; column temperature, $200^{\circ} \mathrm{C} ; \mathrm{N}_{2}$ flow rate, $50 \mathrm{ml} \mathrm{min}^{-1}$.

Preparation of antibody against $L D H$. Two millilitres of a mixed emulsion of equal volumes of purified $\mathrm{Tr}-\mathrm{LDH}$ solution $\left(1 \mathrm{mg} \mathrm{m}^{-1}\right)$ and Freund's complete adjuvant was injected into the foot pads of a guinea pig. At 2 and 4 weeks after the injection, booster injections of $1 \mathrm{ml}$ of the emulsion were performed, and antiserum was obtained by bleeding the animal at 5 weeks after the first injection. The antiserum was fractionated with ammonium sulphate $(40 \%$ saturation) and the precipitate was collected as an IgG fraction. Control serum was prepared with the same method by injecting an emulsion of $0.9 \%$ $\mathrm{NaCl} / 10 \mathrm{~mm}$-Tris/ $\mathrm{HCl}$ buffer and adjuvant.

Reagents. PC (egg-yolk lecithin type XIII-E), LPC (egg-yolk lecithin type 1, 1-palmitoyl-2-oleyl-PC, 1-oleyl-2-palmitoyl-PC, PLase $\mathrm{A}_{2}$ ( Naja naja venom) and PLase B (Vibrio sp.) were purchased from Sigma. Silica gel 60 was purchased from Merck.

\section{Results}

Tr-LDH was purified from the periplasmic fraction of the transformant by ammonium sulphate fractionation and Mono-Q column chromatography (Table 1). The recovery of lecithin-dependent haemolytic activity was $14.8 \%$ of that of the periplasmic fraction. The specific activity was 21 times that of the starting material. Conventional PAGE of the final preparation showed two protein bands (Fig. $1 a$ ). When the acrylamide gel column was embedded in lecithin/blood-agar gel $[1 \%$ $(\mathrm{w} / \mathrm{v})$ agar, $4 \%(\mathrm{v} / \mathrm{v})$ sheep erythrocytes, $3 \%(\mathrm{w} / \mathrm{v}) \mathrm{NaCl}$, $10 \%$ (w/v) lecithin, $50 \mathrm{~mm}$-Tris/ $\mathrm{HCl}$ buffer, $\mathrm{pH} \mathrm{7.5]} \mathrm{and}$ incubated at $37^{\circ} \mathrm{C}$ overnight, a stretched haemolytic zone with a constricted part in the middle was observed around the protein bands. The constricted part was thought to be formed by overlapping of the two haemolytic zones around the two protein bands. The diameters of the haemolytic zones were measured (Fig. $1 b$ ), especially at the constricted and swollen parts. When the gel column was embedded in agar gel $(1 \%$ agar in $50 \mathrm{~mm}$-Tris/ $\mathrm{HCl}$ buffer, $\mathrm{pH} 7.5$ ) and antiserum against $\mathrm{LDH}$ was applied in a trough parallel to the gel 
Table 1. Purification of $\operatorname{Tr}-L D H$

\begin{tabular}{lccccc}
\hline \hline & $\begin{array}{c}\text { Total } \\
\text { volume } \\
(\mathrm{ml})\end{array}$ & $\begin{array}{c}\text { Total } \\
\text { protein } \\
(\mathrm{mg})\end{array}$ & $\begin{array}{c}\text { Total } \\
\text { activity* } \\
(\mathrm{HU})\end{array}$ & $\begin{array}{c}\text { Specific } \\
\text { activity* } \\
(\mathrm{HU})\end{array}$ & $\begin{array}{c}\text { Recovery } \\
(\%)\end{array}$ \\
\hline $\begin{array}{l}\text { Purification step } \\
\begin{array}{l}\text { Priplasmic fraction } \\
\text { ammonation obtained by }\end{array}\end{array}$ & 100 & 144.5 & 315000 & 2180 & 100 \\
$\begin{array}{l}\text { Preparation obtained by } \\
\text { Mono-Q column chromatography }\end{array}$ & 2.3 & 17.2 & 178200 & 10360 & 56.6 \\
\hline \hline
\end{tabular}

- Measured as lecithin-dependent haemolytic activity.

(a)

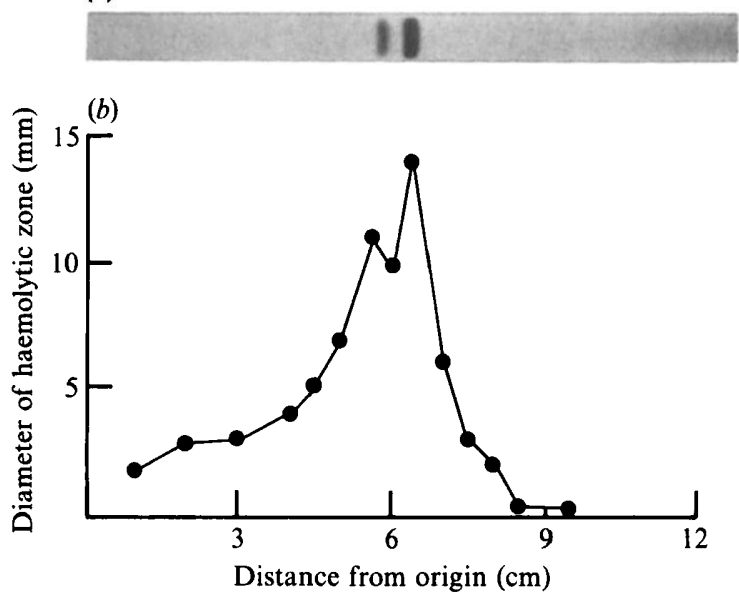

Fig. 1. PAGE of LDH. A Tr-LDH preparation $(50 \mu \mathrm{g}$ protein) obtained by Mono-Q column chromatography was applied to a polyacrylamide gel column. Electrophoresis was carried out by the method of Davis \& Ornstein (1968). One gel was stained with Coomassie brilliant blue (a). Another gel was subjected to the haemolysin assay with blood-agar as described in Methods $(b)$.

column, precipitin arcs were formed against both bands and the arcs fused with each other. These results suggest that the two proteins in the final preparation are both LDH. It is thought that the transformant produces two LDH proteins which are immunologically cross-reactive. SDS-PAGE showed that the molecular masses of the two $\mathrm{Tr}-\mathrm{LDH}$ molecules were 43 and $45 \mathrm{kDa}$. The two proteins, small- and large-sized $\mathrm{Tr}-\mathrm{LDH}$, were designated as $\operatorname{Tr}-\mathrm{LDH}(\mathrm{S})$ and $\operatorname{Tr}-\mathrm{LDH}(\mathrm{L})$, respectively.
The N-terminal amino acid sequences of the two LDHs were determined. As shown in Fig. 2, both sequences were in agreement with the sequence suggested by DNA sequence analysis (Taniguchi et al., 1986). Tr-LDH(S) seems to be a protein which has $15 \mathrm{~N}$ terminal amino acids deleted from the $\operatorname{Tr}-\mathrm{LDH}(\mathrm{L})$ molecule. If so, the molecular masses of these proteins can be calculated as 41453 and $42794 \mathrm{kDa}$, respectively. These values are roughly in agreement with the results from SDS-PAGE.

The final preparation of Tr-LDH that we obtained was a mixture of two proteins, but the above results suggest that both proteins are products of the same gene and have the same haemolytic activity. Therefore, this fraction was used for the study of properties of LDH in subsequent experiments.

Such different-sized LDH molecules were also observed in Vp-LDH. When the partially purified Vp-LDH fraction was applied to conventional PAGE and the gel column was embedded in PC/blood-agar gel, the two overlapped haemolytic zones were observed in the same place as those of Tr-LDH (Fig. 3). In the gel diffusion test, Tr-LDH and Vp-LDH formed a fused precipitin line against anti-Tr-LDH antibody (data not shown).

It is well known that PLase A of snake or bee venom shows indirect haemolytic activity by hydrolysing phospholipids to lysophospholipids, which, due to their surface activity, dissociate erythrocyte membranes. Haemolysis by LDH is caused after the addition of phospholipid, suggesting that LDH has PLase A activity. Thus, the activity of LDH was compared with that of two reference enzymes: PLase $A_{2}$ of snake venom
(A) GCT TCT GCA GTT GCC GAA GAG CCA ACC TTA TCA CCA GAA ATG GTT TCA GCG TCT gAA
(B) Ala Ser Ala Val Ala Glu Glu Pro Thr Leu Ser Pro Glu Met Val Ser Ala Ser Glu
(C)
(D)
Thr Glu Glu Pro Thr Leu Ser Pro Glu Met Val Ser Ala

(A) GTG ATC AGC ACG CAA GAA AAC CAA ACC TAT ACC TAT GTT CGC TGT TGG TAT CGC

(B) Val Ile Ser Thr Gln Glu Asn Gln Thr Tyr Thr Tyr Val Arg Cys Trp Tyr Arg

(D) Val lle Ser Thr Gin Glu Asn? Thr Tyr Thr? Val
Fig. 2. N-terminal amino acid sequences of Tr-LDHs. Lines: A, DNA nucleotide sequence (Taniguchi et al., 1986); B, amino acid sequence suggested by the DNA sequence; $C$ and $\mathrm{D}$, amino acid sequences of $\mathrm{LDH}(\mathrm{L})$ and $\mathrm{LDH}(\mathrm{S})$, respectively, determined in this paper. 


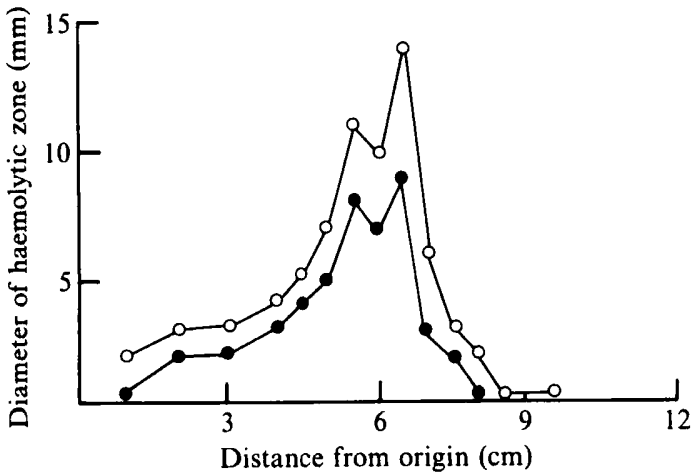

Fig. 3. PAGE of LDHs obtained from $V$. parahaemolyticus $(0,500 \mu \mathrm{g}$ partially purified protein) and transformed $E$. coli $(O, 50 \mu \mathrm{g}$ purified protein). The electrophoresis was carried out by the method of Davis \& Ornstein (1968) and the gel was subjected to the haemolysin assay with blood-agar as described in Methods.
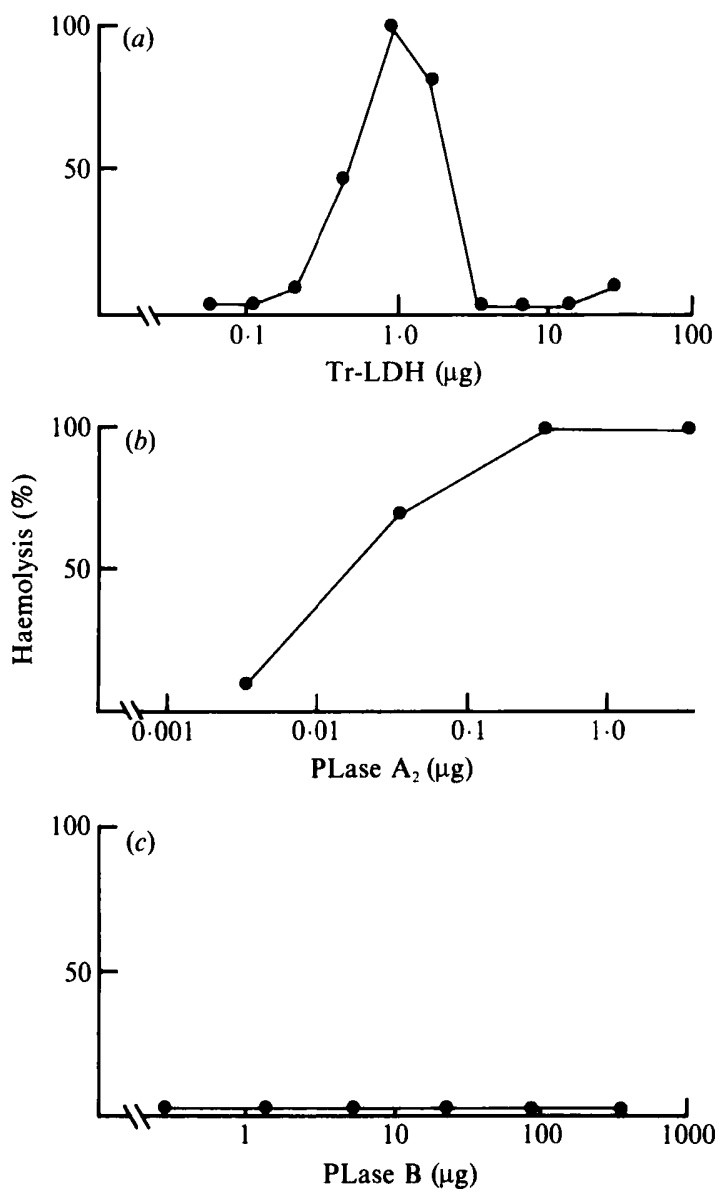

Fig. 4. Haemolytic activity of $\mathrm{LDH}$ and reference enzymes. Tr-LDH (a), PLase $\mathrm{A}_{2}$ of Naja naja venom (b) and PLase B of a Vibrio sp. (c) were subjected to the assay as described in Methods.

and PLase B of a Vibrio species. Fig. 4 shows the haemolytic activities of $\mathrm{Tr}-\mathrm{LDH}$ and the reference enzymes in the test-tube method. Tr-LDH caused haemolysis at low, but not high, concentrations. On the

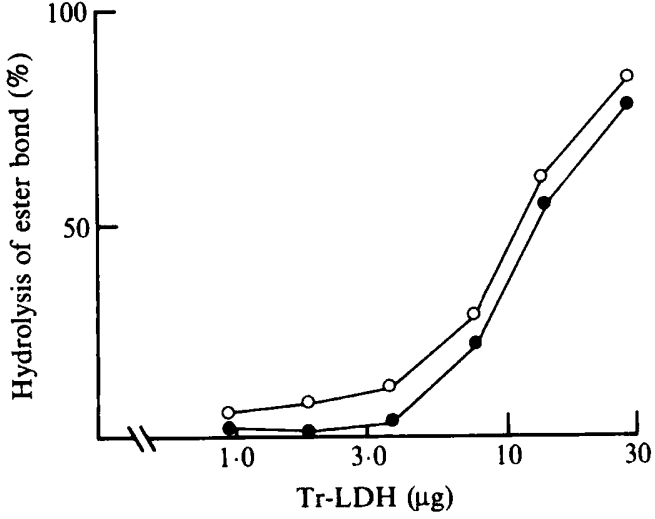

Fig. 5. Hydrolysis of PC (O) and LPC (O) by Tr-LDH. LDH and the substrates were incubated at $37^{\circ} \mathrm{C}$ for $30 \mathrm{~min}$ and the hydrolysis was assayed by the hydroxamate method as described in Methods.

Table 2. Hydrolytic activity of $L D H$ and reference enzymes against phosphatidylcholine and lysophosphatidylcholine

$\mathrm{ED}_{50}$ values $(50 \%$ effective dose: $\mu \mathrm{g}$ enzyme necessary to hydrolyse $50 \%$ of $400 \mathrm{nmol}$ substrate in the assay system) are given; they were determined by the hydroxamate method as described in Methods.

\begin{tabular}{lccr}
\hline \hline Substrate & Tr-LDH & PLase B & PLase A2 \\
\hline Phosphatidylcholine & 13 & 332 & 19 \\
Lysophosphatidylcholine & 12 & 5 & $>1000$ \\
\hline \hline
\end{tabular}

other hand, haemolysis by PLase $\mathrm{A}_{2}$ was dose dependent, and did not disappear at high concentration. PLase B did not show any haemolytic activity at the concentrations used, although it has enough enzymic activity against phospholipid, as shown below. Fig. 5 shows enzymic activity of Tr-LDH against PC and LPC, which was determined by measuring the decrease in the amount of fatty acid ester residues of the phospholipids. Tr-LDH showed almost the same degree of hydrolytic activity to both PC (diglyceride) and LPC (monoglyceride), suggesting that LDH hydrolyses both fatty acid esters of phospholipid at roughly the same rate. The $\mathrm{ED}_{50}$ values $(50 \%$ effective dose: $\mu \mathrm{g}$ enzyme necessary to hydrolyse $50 \%$ of $400 \mathrm{nmol}$ substrate in the assay system) for PC and LPC were almost the same, as shown in Table 2. In contrast, PLase B was more effective on LPC, and PLase $A_{2}$ was effective only on PC (Table 2). These results suggest that $\mathrm{LDH}$ is an enzyme which hydrolyses both fatty acid esters of phospholipid but is different from PLase $B$ in the rate of action against the two fatty acid ester residues.

Fig. 6 shows the results of the phospholipid-agar gel assay of LDH and reference enzymes. Agar gel plates $(1 \%$ agar in $50 \mathrm{mM}$-Tris/ $\mathrm{HCl}$ buffer, $\mathrm{pH} 7.5)$ containing 
(a)

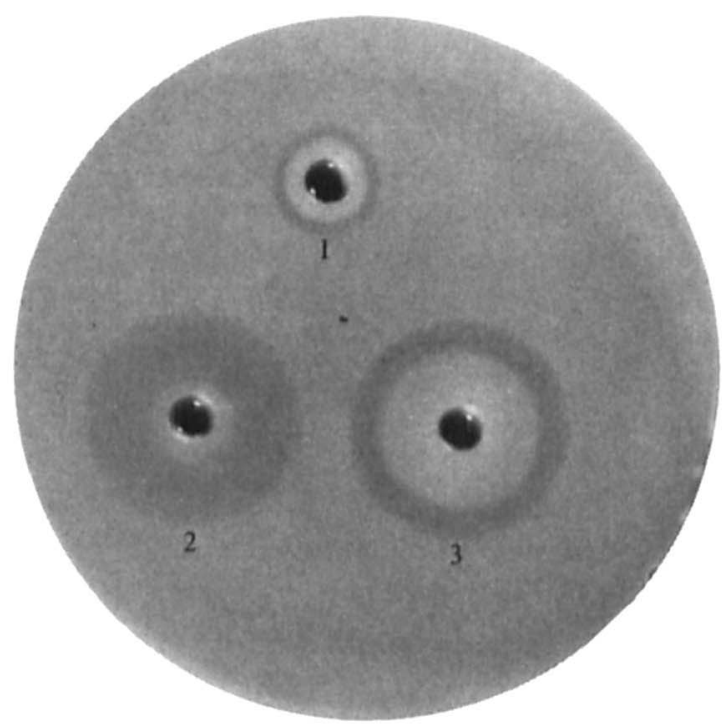

(b)

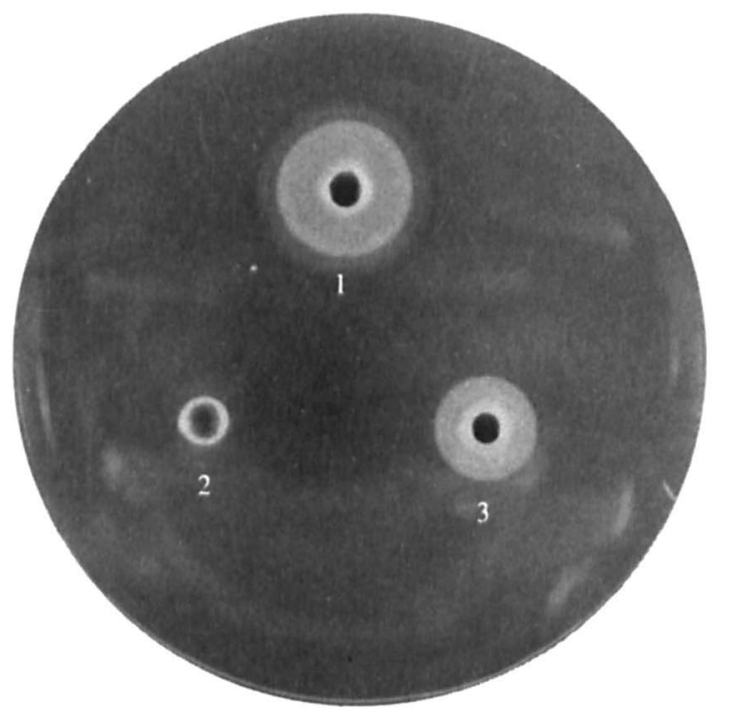

Fig. 6. Enzymic activity of $\mathrm{Tr}-\mathrm{LDH}$ and reference enzymes in agar gels containing phospholipids. Purified PLase B $(350 \mu \mathrm{g})(1)$, PLase $\mathrm{A}_{2}$ $(380 \mu \mathrm{g})(2)$ and $\mathrm{Tr}-\mathrm{LDH}(100 \mu \mathrm{g})(3)$ were placed into wells of agar gels containing phosphatidylcholine $(a)$ or lysophosphatidylcholine $(b)$ and the gels were incubated at $37^{\circ} \mathrm{C}$ as described in Methods.

$0.1 \%$ PC (PC-agar) or $0.1 \%$ LPC (LPC-agar) were prepared, the PLases were applied in the wells and the agar plates were incubated at $37^{\circ} \mathrm{C}$ overnight. In PCagar (an opaque gel because of the insolubility of PC), PLase $\mathrm{A}_{2}$ formed a clear zone around the well, whereas Tr-LDH and PLase B formed a concentric circle, an outer clear ring and an inner turbid zone, the clear ring of PLase B being very thin compared with the inner turbid zone. Gradients of the enzyme concentration formed around the wells. These results suggest, therefore, that PC was partially hydrolysed to soluble LPC in the outer ring and LPC was further hydrolysed to GPC and insoluble free fatty acids in the inner ring. In LPC-agar (a translucent gel because of the solubility of LPC), on the other hand, PLase B and Tr-LDH formed a turbid zone because of insoluble fatty acid, whereas PLase $\mathrm{A}_{2}$ had no effect. Although the same amount of enzyme was applied to both gels, PLase B formed a larger zone in the LPCgel, whereas zones formed by $\mathrm{Tr}-\mathrm{LDH}$ were almost the same in both gels. The extent of the clear or turbid circles in PC-agar corresponds to the progress of the PLase action, i.e. formation of the reaction products: LPC and a free fatty acid in the clear zone, and GPC and two free acids in the turbid zone. To confirm this, chloroform extracts of the circles were applied to a TLC plate. In the extract of the clear zone on PC-agar formed by LDH action, LPC and free fatty acid were detected. In the turbid zone, however, no LPC remained (data not shown). The phospholipid-agar assay thus demonstrated the different reactions of these PLases.

To determine which fatty acid ester of PC was hydrolysed first, PCs with two different fatty acid residues were used for the phospholipid-gel assay. Tr-LDH was applied to the agar gel containing such PCs, and the fatty acid liberated in the outer clear zone, in which only one ester was hydrolysed (as shown above), was determined by gas chromatography. When 2-oleyl-1palmitoyl-PC was used, only oleic acid was detected, whereas palmitic acid was detected from the 2-palmitoyl1-oleyl-PC-agar, suggesting that LDH hydrolysed the ester in the 2-position in the first step (data not shown).

The LDH preparation used in this experiment is a mixture of two immunologically cross-reactive protein molecules. As shown above, the LDH preparation hydrolyses both fatty acid esters of the phospholipid. Therefore, one might suspect that the two proteins have different functions, one being a PLase A hydrolysing diglyceride to monoglyceride and the other, a lyso-PLase hydrolysing the monoglyceride. If so, only one of the two proteins should form a clear zone in PC-agar gel. When the gel of conventional PAGE was embedded in PC-agar gel, however, the double circled zone (outer clear and inner turbid) was formed around both protein bands, suggesting the identity of the activity of the two protein bands.

\section{Discussion}

LDH of $V$. parahaemolyticus was purified from the periplasmic fraction of $E$. coli $\mathrm{C} 600$ transformed by a recombinant plasmid, pHL591, containing a DNA fragment of the chromosome of $V$. parahaemolyticus. 
Purification was accomplished in only two steps, ammonium sulphate fractionation and FPLC with a Mono-Q column. This was easier than purification from culture supernatant of $V$. parahaemolyticus, in which more steps are necessary and the yield is very low (unpublished observation). The LDH (Tr-LDH) obtained from the transformant seems to be identical with LDH produced by $V$. parahaemolyticus ( $\mathrm{Vp}-\mathrm{LDH}$ ), because these LDHs showed the same mobility on PAGE and were cross-reactive in the immuno-gel diffusion test.

The preparation obtained was a mixture of two LDH molecules, $\mathrm{LDH}(\mathrm{L})$ and $\mathrm{LDH}(\mathrm{S})$. Application of the two proteins separated by conventional PAGE to blood- or phospholipid-agar gel revealed that both molecules have the same haemolytic and enzymic activities. The size of the cloned DNA fragment with the LDH gene is $1.5 \mathrm{~kb}$, which is able to encode an approximately $50 \mathrm{kDa}$ protein. Moreover, the fragment contains a promoter region. The sizes of $\mathrm{LDH}(\mathrm{L})$ and $\mathrm{LDH}(\mathrm{S})$ estimated by SDS-PAGE are 45 and $43 \mathrm{kDa}$, respectively. Therefore, it is thought that the two LDH molecules are products of the same structural gene, and are separated in the processing step. Two sites for signal peptidase may exist in the sequence. This was supported by analysis of the $\mathrm{N}$ terminal amino acid sequence of LDHs. The sequences of the regions analysed roughly agreed with the sequence estimated from the DNA sequence (Taniguchi et al., 1986). The sequences suggest that $\mathrm{LDH}(\mathrm{S})$ is a protein in which 15 amino acids of the N-terminal of $\mathrm{LDH}(\mathrm{L})$ are deleted. Such processing seems to take place not only in the transformant but also in the donor, V. parahaemolyticus, because the same haemolytic zones were observed around $\mathrm{Tr}-\mathrm{LDH}$ and $\mathrm{Vp}-\mathrm{LDH}$ migrated by PAGE.

The LDH of $V$. parahaemolyticus has been thought to be a PLase A (Yanagase et al., 1970). The LDH we obtained, however, hydrolysed not only PC to LPC but also LPC to GPC. PLase $A$ is defined as an enzyme hydrolysing one of two fatty acid esters of phospholipid, and PLase $B$ as an enzyme hydrolysing both esters. According to this definition, the LDH that we obtained should be classified as PLase B. However, the activity against LPC (mono-glyceride) of the typical PLase Bs obtained from various sources is much higher than that against PC (diglyceride). Our result in the PC- or LPCagar assays with a commercially available PLase B preparation also showed this property by PLase B. Therefore LPC formed by PLase B action seems to be immediately hydrolysed to GPC. PLase B has no haemolytic activity because the final product, GPC, is no longer a detergent. On the other hand, LPC formed by PLase $A$ action is a detergent which disturbs erythrocyte membranes, leading to haemolysis. Although LDH hydrolyses LPC, the reaction rate is much lower than that of PLase B. Therefore, the intermediate, LPC, is relatively stable and present in sufficient quantity to cause haemolysis, although addition of too much LDH decreases the haemolytic activity because of the rapid hydrolysis of LPC. Thus LDH of V. parahaemolyticus is an atypical PLase, an exceptional PLase B, or a new type of enzyme which should be designated as PLase $\mathrm{A}_{2}$ /lysophospholipase, which has been demonstrated in guinea pigs (Gassama-Diagne et al., 1989). Such an enzyme was also reported in rats (Pind \& Kuksis, 1989), and Nishijima \& Nojima (1974) reported that PLase $A_{1}$ of Mycobacterium phlei has some lysophospholipase activity.

Misaki \& Matsumoto (1978) reported purification of lysophospholipase of $V$. parahaemolyticus. However, this enzyme is a hexamer which has a molecular mass of $89 \mathrm{kDa}$ and cannot hydrolyse PC. Therefore, the LDH reported here is different from lysophospholipase.

This research was supported by a Grant-in-Aid for Scientific Research from the Ministry of Education, Science and Culture of Japan.

\section{References}

Carreau, J. P. \& DubacQ, J. P. (1978). Adaptation of a macroscale to the microscale for fatty acid methyl transesterification of biological lipid extracts. Journal of Chromatography 151, 384-390.

Davis, B. J. \& ORNSTEIN, L. (1968). Disc electrophoresis, acrylamide gel columns. In Methods in Immunology and Immunochemistry, vol. II. pp. 38-47. Edited by C. A. Williams \& M. W. Chase. New York \& London: Academic Press.

ECKerskorn, C., Mewes, W., Goretzki, H. \& LotTspeick, F. (1988). A new siliconized-glass fiber as support for protein-chemical analysis of electroblotted proteins. European Journal of Biochemistry 176, 509519.

Gassama-Diagne, A., Fauvel, J. \& Chap, H. (1989). Purification of a new, calcium-independent, high molecular weight phospholipase $\mathrm{A}_{2}$ /lysophospholipase (phospholipase B) from guinea pig intestinal brush-border membrane. Journal of Biological Chemistry 264, 94709475.

Honda, T., Ni, Y. \& Miwatani, T. (1988). Purification and characterization of a haemolysin produced by a clinical isolate of Kanagawa phenomenon-negative Vibrio parahaemolyticus and related to the thermostable direct haemolysin. Infection and Immunity 56, 961-965.

Honda, T., Ni, Y. \& Miwatani, T. (1989). Purification of TDHrelated haemolysin produced by a Kanagawa phenomenon-negative clinical isolate of Vibrio parahaemolyticus O6:K46. FEMS Microbiology Letters 57, 241-246.

LAEMMLI, U. K. (1970). Cleavage of structural proteins during the assembly of the head of bacteriophage T4. Nature, London 227, 680685.

Misaki, H. \& Matsumoto, M. (1978). Purification of lysophospholipase of Vibrio parahaemolyticus and its properties. Journal of Biochemistry 83, 1395-1405.

Miyamoto, Y., Kato, T., Obara, Y., Akiyama, S., Takizawa, K. \& YAMAI, S. (1969). In vitro haemolytic characteristic of Vibrio parahaemolyticus: its close correlation with human pathogenicity. Journal of Bacteriology 100, 1147-1149.

MiwataNI, T. \& TAKeDA, Y. (1976). Discovery of Vibrio parahaemolyticus. In Vibrio parahaemolyticus: Causative Bacterium of Food Poisoning, pp. 1-5. Tokyo: Saikon Publishing Co. 
NeU, H. C. \& Heppel, A. L. (1965). The release of enzymes from Escherichia coli by osmotic shock and during the formation of spheroplasts. Journal of Biological Chemistry 240, 3685-3692.

Nishida, S. \& TAmiYA, N. (1986). Phospholipase $A_{2}$ of snake and bee venom (in Japanese). Protein, Nucleic Acid and Enzyme 31, 158165 .

NishiJima, M. \& NoJima, S. (1974). Membrane-bounded phospholipase $\mathrm{A}_{1}$ of Mycobacterium phlei (in Japanese). Protein, Nucleic Acid and Enzyme 12, 277-285.

PIND, S. \& KUKsIS, A. (1989). Association of the intestinal brushborder membrane phospholipase $A_{2}$ and lysophospholipase activities (phospholipase B) with a stalked membrane protein. Lipids 24, 357362.

Sakazaki, R., Tamura, K., Kato, T., Obara, Y. \& Yamai, S. (1968) Studies on the enteropathogenic, facultatively halophilic bacteria, Vibrio parahaemolyticus. III. Enteropathogenicity. Japanese Journal of Medical Science and Biology 21, 325-331.

Taniguchi, H., Ohta, H., Ogawa, M. \& Mizuguchi, Y. (1985). Cloning and expression in Escherichia col: of Vibrio parahaemolyticus thermostable direct haemolysin and thermolabile haemolysin genes. Journal of Bacteriology 162, 510-515.
Taniguchi, H., Hirano, H., Kubomura, S., Higashi, K. \& MizuGUCHI, Y. (1986). Comparison of the nucleotide sequences of the genes for the thermostable direct haemolysin and the thermolabile haemolysin from Vibrio parahaemolyticus. Microbial Pathogenesis 1, 425-432.

Taniguchi, H., Kubomura, S., Hirano, H., Mizue, K., Ogawa, M. \& MizuGUCHI, Y. (1990). Cloning and characterization of a gene encoding a new thermostable haemolysin from Vibrio parahaemolyticus. FEMS Microbiology Letters 67, 339-346.

Yanagase, Y., Inoue, K., Ozaki, M., Ochi, T., Amano, T. \& Chazono, M. (1970). Hemolysins and related enzymes of Vibrio parahaemolyticus I. Identification and partial purification of enzymes. Biken Journal 13, 77-92.

Yoh, M., Honda, T. \& Miwatani, T. (1986a). Purification and partial characterization of a non-Ol Vibrio cholerae haemolysin that crossreacts with thermostable direct haemolysin of Vibrio parahaemolyticus. Infection and Immunity 2, 319-322.

Yoh, M., Honda, T. \& Miwatani, T. (1986b). Purification and partial characterization of a Vibrio hollisae haemolysin that relates to the thermostable direct haemolysin of Vibrio parahaemolyticus. Canadian Journal of Microbiology 32, 632-636. 